\title{
Influence of leadership style, training, role of ambiguity on employee performance of higher education of Saudi Arabia (KSA)
}

\author{
Abdullahi Hassan Gorondutse \\ Shahmir Sivaraj Abdullah* Corresponding author \\ Fais Bin Ahmad \\ School of Business Management \\ College of Business Universiti Utara Malaysia \\ Waleed bin Rashed al sherry \\ Directorate of Protocols, King of Saudi Arabia \\ Halilu Bello Rogo \\ Department of Economics and Management Sciences \\ Police Academy Wudil, Kano, Nigeria
}

\begin{abstract}
Keywords
Leadership Styles, Training, Employee Performance, Higher Education and Kingdom of Saudi Arabia (KSA)
\end{abstract}

\begin{abstract}
Employee performance is always considered as one of the important factors of employee management that determines the success of an organization. The higher education sector of any country is considered as an important sector which needs to concentrate on achieving its goals successfully. Thus, this research aimed to investigate effect of leadership and training on employees' performance by taking role ambiguity as a moderating variable in the higher education sector of the Kingdom of Saudi Arabia (KSA). The population of this study consisting of 39154 employees was divided into five groups based on the geographic regions (East, West, Middle, North, and South). This study used the systematic sampling. 600 questionnaires were distributed among the employees working in the higher education system of KSA. 366 questionnaires were returned and were usable for analysis. To test the proposed hypotheses, the Partial Least Squares Structural Equation Modeling (PLS-SEM) was employed. The results found leadership and training have significant positive impacts on employee performance. The study also showed that role ambiguity significantly moderates the relationship between leadership styles with employees' performance in the higher education sector of KSA. Unpredictably, this study found that role ambiguity does not significantly moderate the relationship between training and employees' performance. Role ambiguity negatively influences the relationship of leadership with employees' performance. Therefore, policy-makers and leaders of higher education institutions of KSA should focus on reducing role ambiguity.
\end{abstract}

Corresponding author: Shahmir Sivaraj Abdullah

Email address for corresponding author: shahmir@uum.edu.my

First submission received: $12^{\text {th }}$ December 2017

Revised submission received: $19^{\text {th }}$ February 2018

Accepted: $8^{\text {th }}$ March 2018

\section{Introduction}

Over the past few decades, higher education all over the world has developed momentous changes concerning its role and formation (Alshery \& Ahmad, 2016; Teichler, 1988; Kelo, Teichler, \& Wächter, 2006). In the early twentieth century, higher education was inadequate to a little university outside Europe, North America, and the colonies of Great Britain (Alshery \& Ahmad, 2016; Rohstock \& Lenz, 2011). Therefore, higher education is measured a space for free examination and the developments of the minds and a very good locus for thought, communication, dealings, and thorough for truth or exchanging idea into concensus (Alshery \& Ahmad, 2016; Bagga, Erbe, Murphy, Freid, \& Pomrink, 2007). Including aforementioned important functions of higher education, economic and social demands also 
became important focuses for it. Thus, higher education is no longer limited to the purpose of training for the elite (Alshery \& Ahmad, 2016).

In the context of KSA Management of Saudi higher e education, all the organization and institutional levels, was a main concern; particularly academic leadership in the institutions that create difficulties (Alshery \& Ahmad, 2016); Altrasi, 2014). For instance, academics leader s in KSA institutions interest for advancement in research and teaching may face with difficulties in order to actively play significant role in their institutions

Excellent job performance has to be maintained and employees should be well enriched with the needed skills to guarantee that the business was not in misfortunes because of the absence of obliged attitudes at both levels, broadly and globally (Tomaka, 2001) and higher education sector is not an exemption in this context. According to Smith and Abouammoh (2013), academic staff performance and other related issues such as a student's ability to acquire learning skills, efficient interactive delivery of knowledge, contemporary developed curriculum and overall employee performance standards is one of the major challenges being confronted by Saudi universities. In sum, the Saudi universities have not achieved the required status among international universities due to failing in achieving high-quality teaching and performance standards.

Saudi higher education institutions are facing various problems and challenges to meet global education benchmarks including a partnership among departments, institutions and leadership development to bridge the gaps of quality of the employees' outcomes (Alnassar \& Dow, 2013). The experience of academic leadership development in Saudi Arabia stemmed from a strategic perspective (Smith \& Abouammoh, 2013). Staff training is also regarded as on the challenges that face Saudi universities (Alshery \& Ahmad, 2016; Alnassar \& Dow, 2013; Ratyan \& Mohammad, 2016). In addition, Kattuah (2013) states that there is a lack of skills among academic staff in Saudi universities which involve providing training programs in order to bring them to international standards. It is also argued that lack of the lecturers' awareness level about their roles is not so clear such as research publication and community service in Saudi universities (Jdaitawi, Ishak, \& Foua'd Musallam, 2013). The consequences of the role ambiguity are lower job satisfaction, less productivity, absenteeism and low commitment (Alshery \& Ahmad, 2016; Al-Kahtani \& Allam, 2015). Based on the previous discussion, it is clear that higher education sector in KSA has faced many issues such lower ranking of Saudi universities compared to international universities and underperformed performance of the academic staff due to their leadership issues, lack of training and their role ambiguity.

Likewise, the link between training and employee performance is conflicting as many studies such as Farooq and Khan (2011), Naqvi and Khan (2013), Diab and Ajlouni (2015), Asfaw, Argaw and Bayissa (2015) and Alshery and Ahmad (2016) have proved the significant relationship between the two constructs; whereas other scholars Jones, Jones, Latreille and Sloane (2009) argued that the link between training and employee performance is complex due to the variety of their measurements. Many researchers also argue that training is not the only source to improve the job performance of employees (Murrell, 1984). Al-Gahtani (2002) states that many researchers showing various results regarding the training and job satisfaction to improve the job performance of the employee. Thus, the inconsistent findings regarding the relationship between these variables, namely, leadership and training and employee performance shows that there is an urgent need to examine these relationships in the context of higher education sector in KSA to take a broad view the previous results.

\section{Literature review and hypothesis development 2.1 Leadership and employee performance}

There are numerous approaches to characterize leadership. In view of 54 specialists from 38 nations, the leadership management is about affecting, propelling, and empowering others to contribute to the viability and the accomplishment of an organization (Alshery \& Ahmad, 2016, McShane \& Glinow, 2010). The leadership is additionally characterized by Robbins and Judge (2007) as the capacity to impact a gathering toward the accomplishment of a vision or set of objectives . A less complex definition was given by Kassim and Sulaiman (2011) where they define leadership as to be a piece of administration that includes the supervision of others . Pater (2001) as cited in Lu \& Yang's (2010) study, state that safety 
leadership was highlighted as a sub-system of hierarchical administration Alshery \& Ahmad, 2016; Semedo et al., (2017).

Referring to literature review, the link between job satisfaction and leadership is confirmed. For example, Lee and Wilber (1985) reported a positive relationship between job satisfaction and leadership in their investigation of cops in Malaysia separately. Holdnak, Harsh, and Bushard, (1993) discovered a positive relationship between consideration leadership behaviour and job satisfaction, and negative relationship between initiating structure leadership behaviour and job satisfaction.

Leadership and job performance qualities are the most effective factors that help organisations to achieve their objectives. Leaders can impose decisions on the strength of achievable performance. The goal of all the managers is to increase the production level and to enhance the efficiency to achieve the set targets of the organisation. The positive relationship between job performance and leadership styles influence the improvement and help organisations to achieve the vision and mission with great success (Ullah \& Batool, 2013). Furthermore, more recent studies confirmed that leadership styles have a significantly effect on employees' performance (Wambugu, 2014; Rasool et al., 2015; Girei, 2015; Desderio et al., 2016). Thus, the first hypothesis is specified as follows;

Hypothesis 1: There is a significant effect of the leadership style on performance of employees working in the public universities of KSA.

\subsection{Training and employee performance}

Training can be referring to filling the paucity between the present performance and the usual desired performance (Alshery \& Ahmad, 2016). Training could be given through different methods such as on the coaching and mentoring, peers' cooperation and participation by the subordinates. The past researchers confirmed a positive connection between training and employee performance, as training brings favourable circumstances for the individual adjacent for the firm by completely influencing employee performance through the change of employee's performance and behaviour. The development of employess' capabilities and skills should be given much attention by the firms for the benefits of the on shareholders and customers alike (Alshery \& Ahmad, 2016; Elnaga, \& Imran 2013).

Effective training is useful to the firm in an assortment of routes, for example, it assumes an indispensable part in building and look after capacities, both for the individual and authoritative level, and in this way take an interest during the time spent on hierarchical change (Hamosh et al., 2000). Other research argued that to raise the employee performance organisations should specifically focus on to DK and PKS by shaping personalities, improving training, fulfilling interests, and enhancing the experience (Campbell et al. 1993; Kinicki \& Kreitner; 2007). Thus, the second hypothesis is defined as follows;

Hypothesis 3: There is a significant effect of training on performance of employees working in the public universities of KSA.

\subsection{Role ambiguity as a moderator}

Rizzo, House and Lirtzman (1970) described role ambiguity as the inharmoniousness of the organisational demands from an employee in the reference to his role. Based on the theoretical model developed by Rizzo et al. (1970), there are three dimensions of role ambiguity, namely: 1) organisational factors, 2) personality factors, and 3) interpersonal factors. For organisational factors, role requirements were measured in three areas. First, the role was measured in terms of the extent to which the position crossed outside of the organisation's boundaries or interacted with individuals outside of the organisation. The researchers hypothesised that employees who work close to a boundary - both of the organisation or of a department or work area - experience increased conflict about their role and increased tension. Second, the extent to which an employee's role requires innovative problem-solving for nonroutine problems were measured.

The relationship between ambiguities with employee performance had been widely studied in past researches. Nevertheless, there were often found to have mixed empirical evidence between role ambiguity and performance (Singh, 1993). A meta-analysis based on the work of Jackson and Schuler (1985) by Tubre and Collins (2000) found that in order for an individual to carry out a task effectively, sufficient information is imperative. Alshery and Ahmad (2016) point out that when the employees do not 
understand their job duties well, they may become dissatisfied with their job and the probability to leave the job is higher. It is also stated that the role ambiguity likely affects the relationship between job satisfaction and employee performance (Sum, Mclaughlin, Khatiwada, \& Palma, 2008). Leadership then comes forward and rules out the ambiguities in the head of an employee and let them perform well (Othman, Daud, \& Kassim, 2011). And An employee with a lower job-based maturity will not perform well at their job tasks without the injection of some training sessions (Bougie et al., 2009). Thus, it is needed to examine the moderating effect of the role ambiguity on the relationship between job satisfaction and academic staff performance in the higher education sector in KSA as examining this relationship has been ignored in the literature. Therefore, this study makes an endeavor to study role of ambiguity as a moderator on the relationship between the independent variables namely, training and leadership behaviors and employee performance in the Saudi universities.

Hypothesis 3: Does role ambiguity moderates the relationship between leadership style and the performance of employees working in the public universities of KSA.

Hypothesis 4: Does role ambiguity moderates the relationship between training and the performance of employees working in the public universities of KSA.

\subsection{Underpinning theory}

The model by Campbell is considered as the most important model of job performance in the literature which is compared with a few other related theories of performance theories (Hunter, 1983; Pritchard, \& Costa 1991) and have been adopted by researchers on individual job performance studies (Alshery \& Ahmad, 2016; Law, Wong, Huang \& Li, 2008).

Campbell's (1990) model makes clear distinctions between three components, which comprised of performance components, performance determinants, and the antecedents of performance determinants. Since in this study, the purpose is to look at the determinants of performance components, the antecedents of the determinants are not discussed. However, in general, the antecedents are made up of those variables such as person's abilities, personality, interests, education, experience that was lead to individual differences in performance determinants. Cambell's job performance model sufficiently explains variables of current study's framework like employee job performance (dependent variable), leadership style (independent variable), training (independent variable) and role ambiguity (moderating variable). Thereby, it is adopted as an underpinning theory.

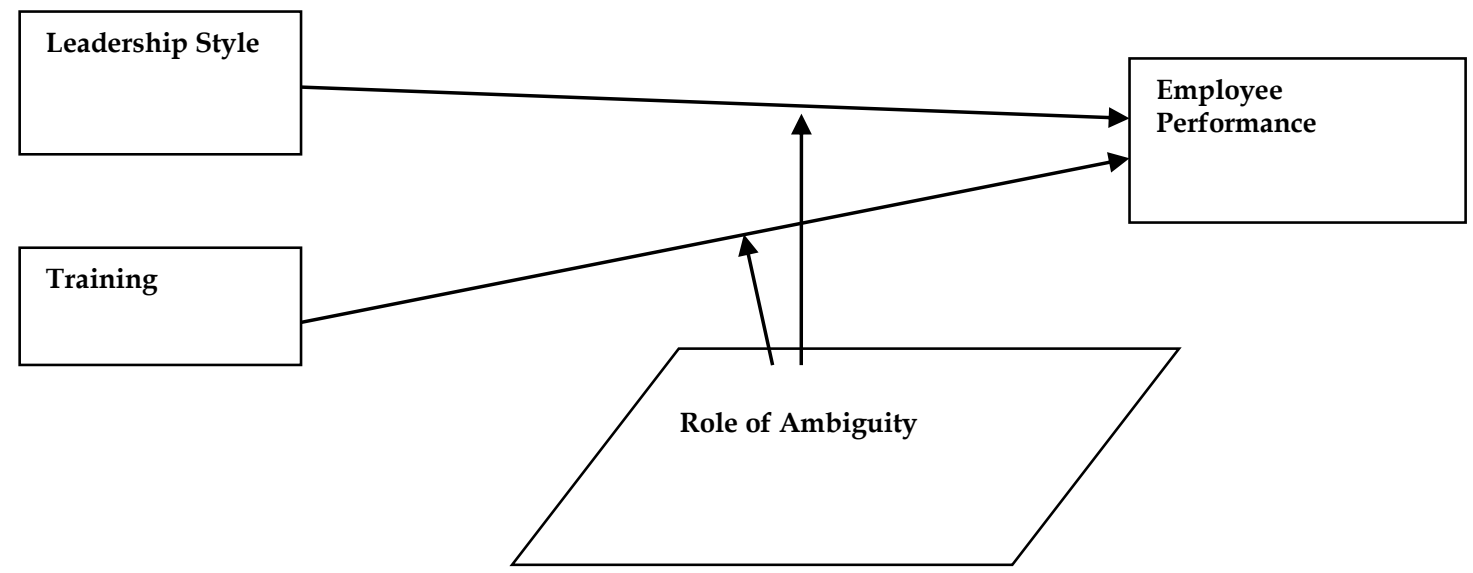

Based on the above framework Cambell's job performance model sufficiently explains variables of current study's framework like job performance (dependent variable), leadership (independent variable), training (independent variable) and role ambiguity (moderating variable).

\section{Methodology}

\subsection{Sample and Data Collection}

Probability simple random sampling was used for this study. Probability sampling was selected because according to Sekaran and Bougie (2013). Another reason for this technique, according to Salkind (2003) it has the ability to reduce the biasness of selecting sample object by the researcher while Cavana, 
Dalahaye, and Sekaran, (2001), acknowledged as the high generalizability technique. The population of the study is the academic staffs who have an administrative position and non-academician staffs of public sector universities in KSA as both are considered as university employees who have lack of a clear set of instructions for guiding one's actions in a particular setting. In order to determine the population of this study, reference was made to a sampling frame that was obtained from the ministry of higher education in Saudi Arabia, which indicated that there are 71976 employees in 26 public universities of KSA. The number of public universities (population of the sample) was divided into five groups based on the geographic regions (East, West, Middle, North, and South), which these universities considered as the largest in each region in KSA.

The paper used proportionate stratified sampling, 384 samples are targeted to be technically acceptable, completed, and returned. However, the recorded response rate for the universities' employees in past studies is between $40-60 \%$ (Sneed, 2007). Thus, this research fulfils the rule of thumb as proposed by Roscoe (1975); therefore, this study increase the number of distributed questionnaires by 56\% $\left(384^{*} 1.56=600\right)$, so 600 questionnaires were distributed to five public university employees in five regions in KSA. The usable rate of response for this paper is $61 \%$ and all constructs achieved the highest reliability above 0.70 .

\subsection{Measurement}

\subsubsection{Employee job performance}

Job performance represents behaviours that are formally evaluated by the organisation as part of the employees' responsibilities and duties (Jex \& Britt, 2008). The researchers also described the employees' performance as an individual level variable; the performance was something that an individual did. The measurement of employees' performance is adapted from the previous research by Williams and Anderson (1991) using a five-point Likert scale ranging from strongly agrees to strongly disagree for job performance scales. Reported reliability by William and Anderson (1991) on the measurement was about 0.91 . The employees were asked to rate their job performance on the selected items.

\subsubsection{Role of ambiguity}

The measurement of role ambiguity was adapted from Rizzo et al. (1970). It consists of sevenpoint Likert scales, ranging from strongly agree to strongly disagree for role ambiguity scales. The reliability of this instrument was reported 0.81 as recorded by Rizzo et al. (1970). Since the nature of role ambiguity is negative, all of the items were reversed scored in which high scores indicated higher role ambiguity.

\subsubsection{Leadership}

Leaders, as defined by Robbins and Judge (2007) as the ability to determine a group toward the accomplishment of a vision or set of destinations . Therefore, a simpler definition was made by (Kassim \& Sulaiman, 2011) as to be part of management that involves the oversight of others . The measurement of leadership is adapted from Yang (2010), which had been applied successfully.

\subsubsection{Training}

Hansson (2007) utilised a universal data set incorporated from 26 nations to analyse the degree of training, which improves performance and resources for training where the essential variable ultimately enhances the performance. The measurement of training is adapted from Hansson (2007). The measurement of training is adapted from Hansson (2007). The researcher was using a five-pointed Likert scale, such as 1- strongly agrees, 2 - Agreed, 3 - Neutral, 4 - Disagreed and 5 - strongly agreed.

\subsection{Analysis Method}

Partial Least Sequential, structural equation modelling (PLS SEM) approach was used as a main analysis technique for the data analysis. Smart PLS 3.0 software application (Ringle et al., 2015) was employed in the analysis and reporting the results.

Descriptive analysis was conducted since Sekaran and Bougie (2013) stated that, it is used to describe the phenomena of interest. Therefore, for the analysis of descriptive information on frequency, mean and standard deviation were analyzed. Frequency determine the frequency of the phenomena 
occur, mean for the average score and standard deviation for the extent of variability. Overall, descriptive analysis was employed for the respondents' characteristics and for the construct.

As stated earlier, this study employed PLS SEM techniques employing PLS path modelling (Wold 1974) using SmartPLS 3.0 (Ringle et al., 2015) to test the theoretical model. PLS path modelling was considered because this technique can examine the relationship between constructs and between latent constructs and indicators simultaneously (Chin, Marcolin, \&Newated, 2003).

\section{Results}

\subsection{Testing of measurement model}

Since all the items are adapted, there is no need to do exploratory factor analysis (EFA) but there is a need to do confirmatory factor analysis (CFA). Items were appropriately allotted to their respective constructs on the basis of confirmatory factor analysis; all items were correctly assigned to their constructs. Construct's validity was determined by two ways. First, the items indicated high loadings on their constructs while they were juxtaposed with the other constructs. Second, the item loadings loaded very significantly upon their respective constructs as per the opinion of Chow \& Chan (2008).

Convergent Validity related to the Measurements

The Table 1 indicated the values concerning the composite reliability varied from 0.759 to 0.901 . And thus, the values surpassed the endorsed value, i.e. 0.6 (Hair, 2010; Fornell \& Larcker, 1981). But the AVE (average variances extracted value) fluctuated between 0.508 and 0.681 that is greater than the recommended value (0.5) of AVE by Hair, Hult, Ringle and Sarstedt (2016). This indicates a good level concerning the validity of the concert related to the employed measures (Barclay, Higgins, \& Thompson, 1995). Hence results authenticate the very convergent validity, which is related to the outer model.

Table

Convergent Validity Concerning the Measurements

\begin{tabular}{|c|c|c|c|c|c|}
\hline Construct & Items & Loading & Cronbach Alpha & $\mathrm{CR}^{\mathrm{a}}$ & $\mathrm{AVE}^{\mathrm{b}}$ \\
\hline \multirow{7}{*}{ Employees' performance } & JP1 & 0.634 & \multirow{7}{*}{0.853} & \multirow{7}{*}{0.889} & \multirow{7}{*}{0.536} \\
\hline & JP2 & 0.839 & & & \\
\hline & JP3 & 0.835 & & & \\
\hline & JP4 & 0.776 & & & \\
\hline & JP5 & 0.733 & & & \\
\hline & JP7 & 0.608 & & & \\
\hline & JP8 & 0.664 & & & \\
\hline \multirow{7}{*}{ Leadership } & LE1 & 0.778 & \multirow{7}{*}{0.874} & \multirow{7}{*}{0.901} & \multirow{7}{*}{0.568} \\
\hline & LE2 & 0.786 & & & \\
\hline & LE3 & 0.797 & & & \\
\hline & LE4 & 0.851 & & & \\
\hline & LE6 & 0.634 & & & \\
\hline & LE7 & 0.634 & & & \\
\hline & LE8 & 0.769 & & & \\
\hline \multirow{6}{*}{ Role Ambiguity } & RA3 & 0.723 & \multirow{6}{*}{0.845} & \multirow{6}{*}{0.875} & \multirow{6}{*}{0.541} \\
\hline & RA4 & 0.734 & & & \\
\hline & RA5 & 0.782 & & & \\
\hline & RA6 & 0.759 & & & \\
\hline & RA7 & 0.764 & & & \\
\hline & RA8 & 0.641 & & & \\
\hline \multirow{4}{*}{ Training } & TR3 & 0.669 & \multirow{4}{*}{0.841} & \multirow{4}{*}{0.894} & \multirow{4}{*}{0.681} \\
\hline & TR6 & 0.842 & & & \\
\hline & TR7 & & & & \\
\hline & TR8 & 0.872 & & & \\
\hline
\end{tabular}




\section{Discriminant Validity related to the Measures}

The differentiated validity concerning the quantifications was authenticated through using the method of Fornell and Larcker (1981). As it has been explained in Table 2 the square root of the average variance extracted (AVE) for all the constructs was put at the diagonal elements related to the correlation matrix. Since the diagonal elements were greater as compared to the elements concerning the row and column where they were placed. This authenticates the differentiated validity of the said outer model. In conclusion, it may be said that after having determined the validity of the construct which is related to the outer model, it is, therefore, presumed that the procured findings concerning the hypothesis testing have to be reliable as well as valid.

\begin{tabular}{lllll}
\multicolumn{5}{c}{ Table 2: The Discriminant Validity Matrix } \\
\hline Construct & $\begin{array}{l}\text { Employees' } \\
\text { performance }\end{array}$ & $\begin{array}{l}\text { Leadership } \\
\text { style }\end{array}$ & $\begin{array}{l}\text { Role } \\
\text { Ambiguity }\end{array}$ & Training \\
\hline $\begin{array}{l}\text { Employees' } \\
\text { performance }\end{array}$ & 0.732 & & & \\
Leadership & 0.083 & 0.633 & & \\
Role Ambiguity & -0.231 & -0.138 & 0.735 & \\
Training & 0.513 & 0.329 & -0.023 & 0.825 \\
\hline
\end{tabular}

\section{2 Predictive Relevance and the Quality of the Model}

Result regarding the quality of the prediction related to the said model is shown in Table 3, that clarified the cross-validated redundancy concerning Employees' performance was 0.219189. So, this value was greater than zero, which indicated an adequate predictive validity related to the model which relies upon the criteria proposed by Fornell and Cha (1994).

Table 3: The Model's Predictive Quality Indicators

\begin{tabular}{lllll}
\hline Variable & $\begin{array}{l}\text { Variable } \\
\text { Type }\end{array}$ & R square & $\begin{array}{l}\text { Cross-validated } \\
\text { Communality }\end{array}$ & $\begin{array}{l}\text { Cross-validated } \\
\text { Redundancy }\end{array}$ \\
\hline $\begin{array}{l}\text { Employees' } \\
\text { performance }\end{array}$ & Endogenous & 0.426 & 0.386831 & 0.219189 \\
\hline
\end{tabular}

\subsection{Structural Model Assessment}

Hair et al. (2011) viewed structural model as a model that test the hypothesized direct relationship between endogenous and exogenous variables. Whereby, in partial least squares, structural model explains on the directional association between the constructs and their $t$-values as well as the path coefficient. Referring to the path coefficient, partial least squares are considered by Argawal and Karahanna (2000), are the same as the standardized beta coefficient in regression analysis.

\subsubsection{Examining the Direct Relationships}

The previous studies associated the results which were found out of the analysis that was carried out for the development of the hypothesis, the direct effect of role ambiguity among employees' performance and an explanatory variable, namely, training and leadership as shown above in Table 4

Table 4: The Results concerning the inner structural model (Direct Hypothesis Testing)

\begin{tabular}{lllllll}
\hline Hypothesis & & $\begin{array}{l}\text { path } \\
\text { Coefficient }\end{array}$ & $\begin{array}{l}\text { standard } \\
\text { Error }\end{array}$ & T-value & $\begin{array}{l}\text { P- } \\
\text { value }\end{array}$ & Decision \\
\hline $\begin{array}{l}\text { Leadership } \\
\text { performance (H1) }\end{array}$ & Employees' & $0.035^{* *}$ & 0.105 & 1.733 & 0.042 & Supported \\
$\begin{array}{l}\text { Training > Employees' } \\
(\mathrm{H} 2)\end{array}$ & $0.397^{* *}$ & 0.079 & 5.005 & 0.000 & Supported \\
\hline
\end{tabular}

*: $\mathrm{p}<0.1 ;{ }^{* *}: \mathrm{p}<0.05 ;{ }^{* * *}: \mathrm{p}<0.01$

\section{Discussion}

Hypothesis 1: There is a significant effect of leadership style on the employee's performance who is working in the public sector universities in Saudi Arabia. 
The bootstrapping technique was employed to test the hypothesis. The results show that leadership has a significant and positive effect on employees' performance $(\beta=0.035, t=1.733, p<0.05)$. In this study, the model proved significant and positive results. Thus, this supports the second hypothesis of this research. The results of the current study pertinent to the relationship of leadership and employee performance are contrary to the past studies. Several past studies have found a significant and positive relationship between the leadership and the employee's performance. For instance, motivation and leadership always bring and develops motivation among employees that ultimately affects employee work standards positively. This result is in line with previous studies including Rasool, Arfeen, Mothi and Aslam (2015), Girei (2015); Semedo et al., (2017); Desderio, Piason \& Bhebhe (2016). From the above result, it is evident that there exists a positive relationship between leadership as well as the performance of employees. Results of current research are in line with the previous research as showing the significant and positive relationship that exists between leadership and performance of the employee. The current research also reveals if public sector universities of KSA want to enhance employee performance, they should focus on leadership aspect among academic who has an administrative position and non-academic employees.

Hypothesis 2: There is a significant effect of training upon employees' performance who is working in the public sector universities in Saudi Arabia.

Training has a significant as well as the positive impact upon employee's performance, which is the third independent factor that influences the employees' performance in this research $(\beta=0.397, t=5$. $005, \mathrm{p}<0.01)$. In this study, the model reaches statistically significantly. Hence, the third hypothesis test of the current research is underpinned. The result of the current study is line with various previous studies that also showed the same result such as Farooq and Khan (2011), Naqvi and Khan (2013), Diab and Ajlouni (2015), Asfaw et al. (2015) and Alshery and Ahmad (2016). However, Jones et al. (2009) argued that the link between training and employee performance is complex due to the variety of their measurements. Current studies unfolds the relationship existing between training and performance of the employee in public sector universities in KSA. The current study shows the significant and positive relationship existing between training and performance of the employee. So, this study implicates that in order to uplift the employee performance, training is a significant factor among academic who has an administrative position and non-academic employees of public universities of KSA.

\subsection{Testing the Moderation Effect of Role Ambiguity}

In this section, Figure 2 represent the moderating effect of role ambiguity between employees' performance and independent variable (training, and leadership) as shown above in Table 5.

Table 5: The Results of the Inner Structural Model for Moderating Role Ambiguity

\begin{tabular}{llllll}
\hline Hypothesis & $\begin{array}{l}\text { Path } \\
\text { coefficient }\end{array}$ & $\begin{array}{l}\text { Standard } \\
\text { error }\end{array}$ & T-Value & $\begin{array}{l}\text { P- } \\
\text { Value }\end{array}$ & Decision \\
\hline $\begin{array}{l}\text { Role Ambiguity * Leadership }> \\
\text { Employees' performance (H3) }\end{array}$ & $-0.259^{* *}$ & 0.148 & 1.746 & 0.041 & Supported \\
$\begin{array}{l}\text { Role Ambiguity * Training } \\
\text { Employees' performance (H4) }\end{array}$ & 0.023 & 0.079 & 0.113 & 0.455 & $\begin{array}{l}\text { Not } \\
\text { Supported }\end{array}$
\end{tabular}

*: $\mathrm{p}<0.1{ }^{* *}: \mathrm{p}<0.05 ;{ }^{* * *}: \mathrm{p}<0.01$

Hypothesis 3: Role ambiguity moderates the relationship existing between leadership style as well as the employees' performance who are working in the public sector universities in Saudi Arabia.

Role ambiguity has significant and negatively influence the relation of leadership and performance on the job $(\beta=-0.259, \mathrm{t}=1.746, \mathrm{p}<0.05)$. In this study, the model reaches statistics significant values which mean that role ambiguity significantly and negatively moderates the relationship existing between the leadership and the employees' performance. Resultantly, the hypothesis (H5) of this research is supported. Above result of hypothesis shows that in order to enhance the performance of the employees through leadership style in higher education institutions of KSA should clarify shows the role of each employee in reducing role ambiguity. It is a core responsibility of the leader to enlighten his 
follower by clarifying and educating that what he/she ought to do for the attainment of organisational objectives.

It is in line with the findings of Kassim et al. (2011) who asserted that role ambiguity is one of the most crucial impediments that hinder the employees to achieve their optimum level of performance. He further stated that in the case of role ambiguity leader should come in the front and clear the ambiguities so that employees may feel satisfied and attain organisational objectives. Judge et al. (2007) also asserted the similar findings that it is the leader who eradicates the role ambiguities from the minds of the employees to transform them to be more comfortable as well as loyal to their respective organisation so that they may perform higher.

Hypothesis 4: Role ambiguity moderates the training relationship as well as the employees' performance who are working in the public sector universities in Saudi Arabia.

Role ambiguity has no significant effect on the relationship between training and employees' performance $(\beta=0.023, t=0.113, p>0.1)$. In this study, the model reaches statistically significant which means that role ambiguity, not significantly moderate the relationship that exists between training and employees' performance. Resultantly, the hypothesis (H6) of the research is not supported.

Sekaran and Bougie (2013) explained that organisations provide adequate training to its employees to enhance their skills and abilities to perform their task effectively and efficiently. Role ambiguity confuses the employees and any kind of training would be futile activity as long as employees are not aware of their role and responsibility through proper training mechanism (Bougie et al., 2009). Role ambiguity has constantly been the focus of studies in the field of human performance.

A logical employee can only experience one or the other end of the continuum as when work is performed from the opposite end of the ambiguity of the role is unclear. Jackson and Schuler (1985) emphasised the importance of understanding their role, from an individual perspective, it is believed to influence your own motivation, satisfaction, and performance.

Figure 2 provides plot of the interaction between leadership and role ambiguity on employees' performance at high and low leadership based on the recommendation of Madera, Dawson and Neal (2013). As shown in Figure 2, the relationship between leadership and employees' performance was strongest among employees in public universities in the case of low role ambiguity and weak in the case of high role ambiguity. Individuals of different level of role ambiguity did not differ much in performance under conditions of high leadership, but large differences were noted under conditions of low leadership. In other words, under conditions of low leadership, individuals reporting higher levels of role ambiguity than under conditions of high leadership which individuals reporting lower levels of role ambiguity.

Figure-2

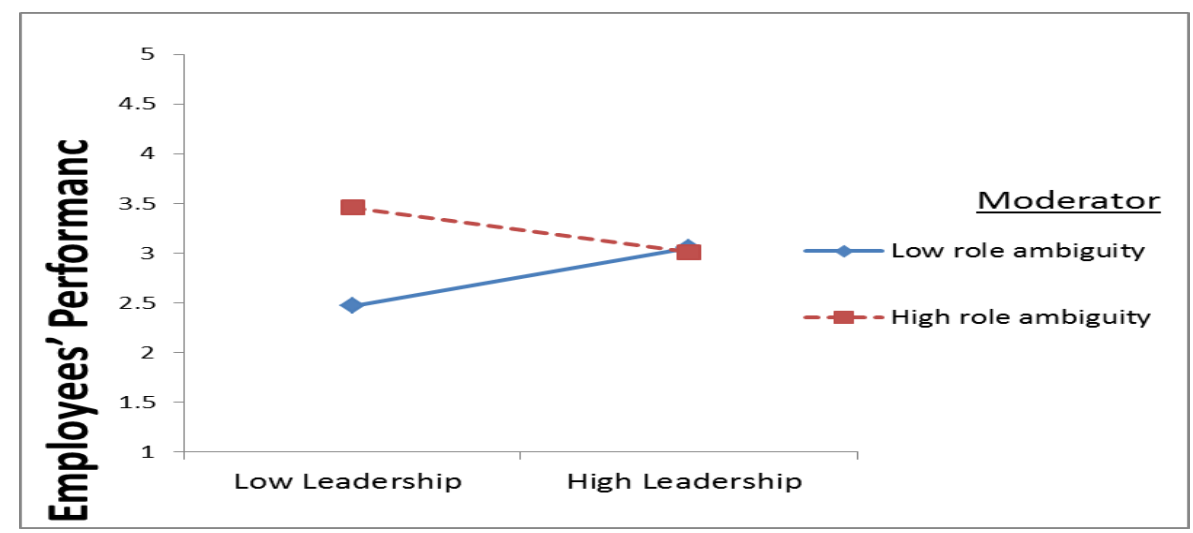

Plot of Interaction between Leadership and Role Ambiguity on Employees' Performance

\section{Conclusion}

This study explores the effect of the main variables, including leadership, and training on employees' job performance via examining the role ambiguity as moderator in the KSA's higher education sector. The main motivation of this study is to improve the employees' performance concerning the higher 
education sector of the kingdom of KSA while identifying the vital role of various variables including job satisfaction, leadership, and training while highlighting the importance of role ambiguity as being a moderating variable.

\subsection{Implications, Limitations, and Suggestion for Future Research}

This study contributes to the existing body of knowledge in understanding the employees' performance as this is the first study with the set of such variables. In other words, this study attempts to increase the understanding of the relationship which is between job satisfaction, leadership, training as well as the performance of employees with the moderating role of role ambiguity in higher education institutions of KSA.

The present study's results have implications for higher authorities, decision makers, and policy planners. This study raises the importance of employee performance in the higher education institutions of KSA. In addition, impacts of various other variables have also been examined, including leadership, job satisfaction and training as predictors and the role ambiguity as being the moderator.

Secondly, this study demonstrated the importance of job satisfaction, leadership, and training in improving the employees' performance. And the results indicate that training was the most important variable which significant predictor of the employees' performance. There are clear, practical implications of these findings. Employee performance has been a matter of quest and research in almost all industries due its importance and higher education institutions are not different in this regard. Job satisfaction urges the employee to put their optimum effort to attain their objectives aligned with the objectives of the organisation.

Despite the insight offered, this study has several limitations that should be considered by future studies. Firstly, this study incorporates only public sector universities that affect the employee performance in the higher education institutions of KSA. To address the limitation, it is strongly recommended that longitudinal studies should be conducted to examine the impact of job satisfaction, leadership style and training on employee performance with the same or different moderator. Further study can be extended by doing multi-sector analysis as well as a comparison of various industries. It was fruitful to have a better insight of employee performance by analysing more variables that are not considered in the current study.

\section{References}

Al-Kahtani, N. S., \& Allam, Z. (2015). Communication Climate as Predictor of Role Conflict among Subordinate Staff of Salman bin Abdulaziz University. Asian Social Science, 11(12), 248.

Alnassar, S. A., \& Dow, K. L. (2013). Delivering high-quality teaching and learning for university students in Saudi Arabia. In Higher Education in Saudi Arabia (pp. 49-60). Springer Netherlands.

Alshery, W. B. R., \& Ahmad, F. B. (2016). The Impact of Job Satisfaction, Training and Leadership on Performance of Employees While Taking Role Ambiguity as a Moderating Variable: Empirical Study on Public Universities of KSA. International Business Management, 10(12), 2460-2473.

Altrasi, M. A. (2014). Determinants of Performance among Public Sector Managers in Saudi Arabia: An analysis of the organizational factors and job attitudes. Middle-East Journal of Scientific Research, 22(3), 409-416.

Anderson, J. C., \& Gerbing, D. W. (1988). Structural equation modeling in practice: A review and recommended two step approach. Psychological Bulletin, 103, 411-423.

Anderson, J. R. (2006). Managing employees in the service sector: A literature review and conceptual development. Journal of Business and Psychology, 20(4).

Asfaw, A. M., Argaw, M. D., \& Bayissa, L. (2015). The Impact of Training and Development on Employee Performance and Effectiveness: A Case Study of District Five Administration Office, Bole Sub-City, Addis Ababa, Ethiopia. Journal of Human Resource and Sustainability Studies, 3(04), 188.

Bagga, C., Erbe, E. M., Murphy, J. P., Freid, J. M., \& Pomrink, G. J. (2007). U.S. Patent No. 7,238,203. Washington, DC: U.S. Patent and Trademark Office.

Barclay, D. W., Higgins, C. A., \& Thompson, R. (1995). The partial least squares approach to causal modeling: personal computer adoption and use as illustration. Technology Studies, 2(2), 285-309.

Blondal S. Field, S. G. N. (2002). Investment in human capital through upper-secondary and tertiary education. OECD Economic Studies, 34 (34), 41-90.http://doi.org/10.1787/eco_studies-v2002-art3-en

Boles, J., Madupalli, R., Rutherford, B., \& Wood, J. A. (2007). The relationship of facets of salesperson job satisfaction with affective organizational commitment. Journal of Business $\mathcal{E}$ Industrial Marketing, 22, 311-321. http://doi.org/10.1108/08858620710773440 
Bougie, J. K., Lim, T., Farah, C. A., Manjunath, V., Nagakura, I., Ferraro, G. B., \& Sossin, W. S. (2009). The atypical protein kinase C in Aplysia can form a protein kinase M by cleavage. Journal of neurochemistry, 109 (4), 1129 1143.

Campbell, J. D. (1990). Self-esteem and clarity of the self-concept. Journal of personality and social psychology, 59 (3), 538.

Campbell, J. P., McCloy, R. A., Oppler, S. H., \& Sager, C. E. (1993). A theory of performance. Personnel selection in organizations, 3570 .

Chin, W.W., Marcolin, B.L. \& Newsted, P.R. (2003). A partial least squares latent variable modelling approach for measuring interaction effects: results from a Monte Carlo simulation study and an electronic-mail emotion/adoption study, Information Systems Research, 14(2), 189-217.

Chow, W. S., \& Chan, L. S. (2008). Social network, social trust and shared goals in organizational knowledge sharing. Information and Management, 45(7), 458-465.http://doi.org/10.1016/j.im.2008.06.007

Desderio M. C., 2. Piason N. \& Bhebhe T. (2016). Leadership style and employee performance in Parastatals: A case of the transport sector. Journal of Business Management Science, 2(1), 69-86.

Diab, S. M., \& Ajlouni, M. T. (2015). The influence of training on employee's performance, organizational commitment, and quality of medical services at Jordanian private hospitals. International Journal of Business and Management, 10(2), 117.

Elnaga, A., \& Imran, A. (2013). The Effect of Training on Employee Performance. European Journal of Business and Management, 5 (4), 137-147. http://doi.org/10.2991/gecss-14.2014.90

Farooq, M., \& Khan, M. A. (2011). Impact of training and feedback on employee performance. Far east journal of psychology and business, 5(1), 23-33.

Fornell, C., \& Cha, J. (1994). Partial least squares. Advanced methods of marketing research, 407(3), 52-78.

Fornell, C., \& Larcker, D. F. (1981). Structural equation models with unobservable variables and measurement error: Algebra and statistics. Journal of marketing research, 382-388.

Gorondutse, A.H., \& Hilman, H. (2016). The Moderation Effect of Organizational culture on the Relationship between Commitments of Corporate Social Responsibility (CSR) and Performance of SMEs in Nigeria. Journal of General Management, 42(1), 65-77.

Girei, A. A. (2015). Perceived Effects of Leadership Styles on Workers' Performance in Package Water Producing Industry in Adamawa State, Nigeria. . International Journal for Innovation Education and Research, 3(12).

Hair, J. F. (2010). Multivariate data analysis. Pearson College Division.

Hair, Jr, J. F., Hult, G. T. M., Ringle, C., \& Sarstedt, M. (2016). A primer on partial least squares structural equation modeling (PLS-SEM). Sage Publications.

Hamosh, A., Scott, A. F., Amberger, J., Valle, D., \& McKusick, V. A. (2000). Online Mendelian inheritance in man (OMIM). Human mutation, 15(1), 57- 61.

Hampton, R., Dubinsky, A. J., \& Skinner, S. J. (1986). A model of sales supervisor leadership behaviour and retail salespeople's job-related outcomes. Journal of the Academy of Marketing Science, 14 (3), 33-43. http:/ / doi.org/10.1007/BF02723262.

Jackson, S. E., \& Schuler, R. S. (1985). A Meta-Analysis and Conceptual Critique of Research on Role Ambiguity and Role Clarity in Work Settings. Organizational Behaviour and Human Decision Processes, 36, 16-78. http:/ / doi.org/10.1016/0749-5978 (85)90020-2.

Jdaitawi, M., Ishak, A. A. S. N. A., \& Foua'd Musallam, L. A (2013). S. The Moderating Role of Tolerance Ambiguity in the Stressors-Strain Relationship: An Empirical Study among University Lecturers in Saudi Arabia.

Jex, S. M., \& Britt, T. W. (2008). Leadership and influence processes. Organizational Psychology: A Scientist-Practitioner Approach, 2, 303-338.

Kassim, Z. A., \& Sulaiman, M. (2011). Market Orientation and Leadership Styles of Managers in Malaysia. International Journal of Leadership Studies, 6(2), 230-245.

Katerberg, R., \& Hom, P. W. (1981). Effects of within-group and between-group variation in leadership. Journal of Applied Psychology, 66(2), 218.

Kattuah, S. E. (2013). Workforce training for increased productivity in Saudi Arabia (Doctoral dissertation,Victoria University).

Law, K. S., Wong, C. S., Huang, G. H., \& Li, X. (2008). The effects of emotional intelligence on job performance and life satisfaction for the research and development scientist in China. Asia Pacific Journal of Management, 25(1), 51-59.

Lee, R. \& Wilber, E.R. (1985). Age, education, job tenure, salary, job characteristics, and job satisfaction: a multivariate analysisll. Human Relations, 38: 781-91.

Leonard-Barton, D. (1992). Core capabilities and core rigidities: A paradox in managing new product development. Strategic management journal, 13(S1), 111-125.

Lu, C. S., \&Yang, C. S. (2010). Safety leadership and safety behavior in container terminal operations. Safety Science, $48,123-134$ 
McShane, S \& Von Glinow, M, (2010). Organizational behaviour: emerging knowledge and practice for the real world.

Mincer, E. I., \& Siegel, D. L. (1993). U.S. Patent No. 5,262,875. Washington, DC: U.S. Patent and Trademark Office. Ministry of Higher Education. (2014). Higher Education in the Kingdom of Saudi Arabia: National indicators: National Indicators and International Comparisons. Retrieved from https://www.mohe.gov.sa/

Othman, K. A., Daud, M. N., \& Kassim, R. S. R. (2011). The moderating effect of neuroticism on the relationship between emotional Intelligence and job performance. Australian Journal of Basic and Applied Sciences, 5(6), 801813.

Pfeffer, J. (1994). Competitive Advantage through People. Harvard Business School Press, Boston, MA

Pool, S. W. (2010). The Relationship of Job Satisfaction with Substitutes of Leadership, Leadership Behaviour, and Work Motivation. The Journal of Psychology, 131 (3), 271- 283. http:/ / doi.org/10.1080/00223989709603514

Rasool, H. F., Arfeen, I. U., Mothi, W., \& Aslam, U. (2015). Leadership styles and its impact on employee's performance in health sector of Pakistan. University Research Journal, 5(1).

Rizzo, J. R., House, R. J., \& Lirtzman, S. I. (1970). Role conflict and ambiguity in complex organizations. Administrative science quarterly, 150-163.

Rohstock, A., \& Lenz, T. (2011). The Making of the Luxembourger. Histories of Schooling and National Identity in the Grand Duchy. Encounters on Education, 12, 61.

Roscoe, J. T. (1975). Fundamental research statistics for the behavioural sciences [by] John T. Roscoe. New York, NY: Holt, Rinehart and Winston.

Sekaran, U., \& Bougie, R. (2013). Research method for business: A skill building approach.

Semedo, A. S.D., Coelho, A. F.M., \& Pareira, M. N. (2017). Authentic Leadership and Creativity, the Mediating role of Happiness. International Journal of Organizational Analysis, 25(3), 395-412.

Singh, A. (1993). The plan, the market and evolutionary economic reform in China. United Nations Conference on Trade and Development (UNCTAD).

Smith, L., \& Abouammoh, A. (2013). Higher Education in Saudi Arabia. London: Springer.

Sum, A., McLaughlin, J., Khatiwada, I., \& Palma, S. (2008). The continued collapse of the nation's teen job market and the dismal outlook for the 2008 summer labor market for teens: Does anybody care. Center for Labor Market Studies.

Tomaka, L. A. (2001). Workforce Development in the Midwestern Region. The Journal of State Government, 26-27.

Tubre, T. C., \& Collins, J. M. (2000). Jackson and Schuler (1985) Revisited: A Meta-Analysis of the Relationships Between Role Ambiguity, Role Conflict, and Job Performance. Journal of Management, 26 (1), $155-169$. http:/ / doi.org/10.1177/014920630002600104

Ullah \& Batool, M., (2013). Impact of Job Satisfaction on Organizational Commitment in Banking Sector: Study of Commercial Banks in District Peshawar. International Review of Basic and Applied Sciences, 1 (2), 12-24.

Wambugu, L. (2014). Effects of Organizational Culture on Employee Performance (Case Study of Wartsila-kipevu Ii Power Plant). European Journal of Business and Management, 6(23). 